Удк 519.682.5

\title{
ДИСТАНЦІЙНЕ НАВЧАННЯ У МЕРЕЖІ WЕВ 3.0
}

\author{
С. М. Петрик \\ ДВНЗ "Прикарпатський національний університет імені В. Cтефраника"

\begin{abstract}
У статті здійснено аналіз існуючих способів ідентифрікації інформації у Семантичному Вебі, окреслено основні проблеми його впровадження та досліджено можливість використання Семантичного Вебу як складової частини дистанційного навчання. Запропоновано альтернативний варіант ідентифікації і побудови взаємозв'язку інформації та набутих знань на основі розробленого методу «спектр знань».
\end{abstract}

Ключові слова: система дистанційного навчання, адаптивний процес, блок матеріалу, спектр знань.

\section{ДИСТАНЦИОННОЕ ОБУЧЕНИЕ В СЕТИ WЕВ 3.0}

\section{ГВУЗ "Прикарпатский национальный университет имени В. Стефраника"}

В статье проведен анализ существующих способов идентификации информации в Семантическом Вебе, обозначены основные проблемы его внедрения и исследована возможность использования Семантического Веба как составной части дистанционного обучения. Предложен альтернативный вариант идентификации и построения взаимосвязи информации и приобретенных знаний на основе разработанного метода «спектр знаний».

Ключевые слова: система дистанционного обучения, адаптивный процесс, блок материала, спектр знаний.

\section{DISTANCE LEARNING ONLINE WEB 3.0}

\section{SHEI "Precarpathian National University by V. Stefanyk"}

C. M. Petryk

This article analyzes the existing methods of identification information in the semantic web, outlines the main problems of its implementation and researches the use of Semantic Web as the part of distance learning. Proposed alternative variant of identification and relationship construction of information and acquired knowledge based on the developed method "spectrum of knowledge".

Key words: system of distance learning, adaptive process, block of material, spectrum of knowledge.

Вступ. Епоха універсального Інтернет закінчується. Розпочинається впровадження технології, яка отримала назву «Семантичний Веб», що являє собою Internet, де вся інформація спеціально відформатована не тільки для зручності людини, а також і для зручності машин, які будуть 3 нею активно працювати. Завдяки цьому з'являються нові можливості з обробки інформації. Однак насамперед мають бути розроблені стандарти кодування інформації (як наприклад, RDF (Resource Description Framework)). Головне, що семантичні технології використовують структуровану інформацію. Це дозволяє суттєво спростити пошук знань в мережі, а головне - ефективніше працювати з ними. В свою чергу, з'являються нові можливості в організації дистанційного навчання.
Мета дослідження - розглянути можливості розвитку і використання Семантичного Вебу як складової частини дистанційного навчання.

Виділені основні проблеми впровадження Семантичного Вебу, розглянуті можливості використання Семантичного Вебу як складової частини дистанційного навчання.

Результати та їх обговорення. На сьогоднішній день історично склалося так, що структура даних в мережі Internet недостатньо пристосована для машинного аналізу. Для вирішення цієї проблеми здійснено глобальну ініціативу реорганізації структури даних Internet 3 метою перетворення його в семантичну павутину згідно з моделлю Семантичного Вебу (рис. 1) i надання можливості ефективного пошуку та аналізу даних як людиною, так і програмними агентами.

О С. М. Петрик 


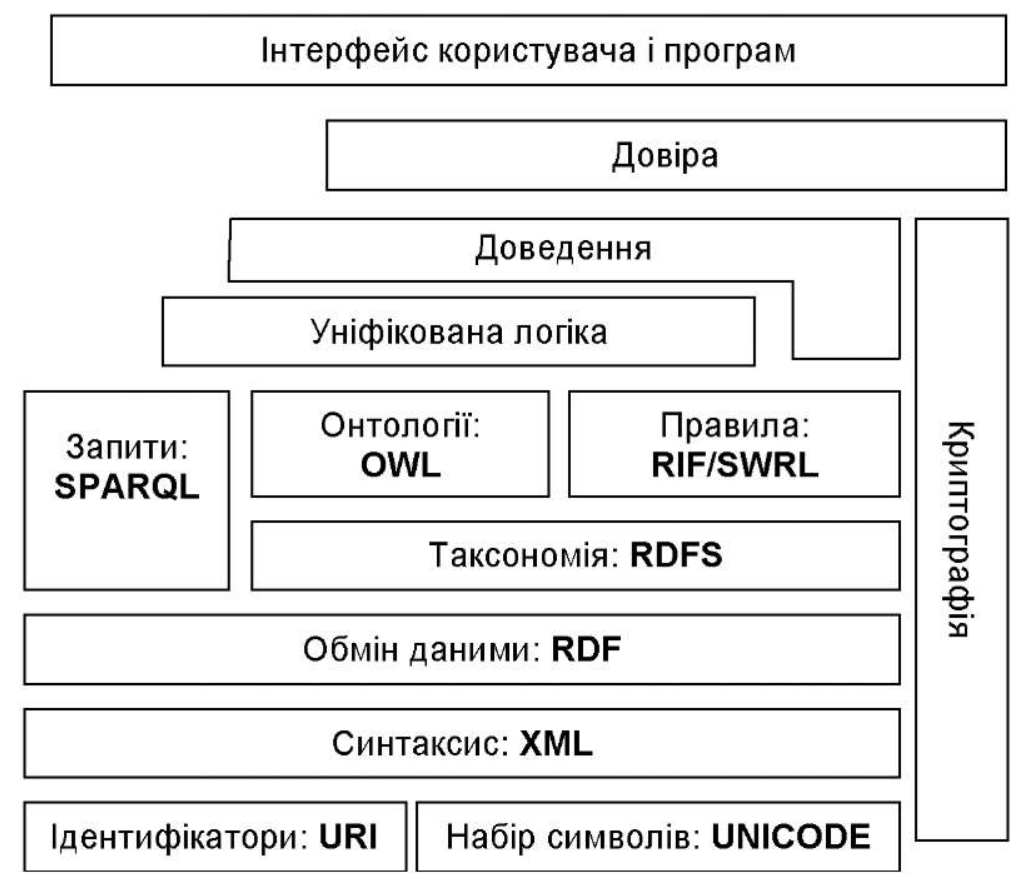

Puc. 1. Стек понять Семантичного Всбј.

Основною рушійною ідеєю при створенні стала необхідність забезпечення «розуміння» алгоритмами обчислювальних машин сенсу (семантики) даних.

Вихідним завданням цих семантичних технологій було забезпечення можливостей вилучення знань 3 пов'язаних між собою наборів інформації. Для вирішення подібних проблем використовуються онтології, які дозволяють описати будь-яку предметну область у зрозумілих для машини термінах і ефективно використовувати мобільні агенти. При використанні такого підходу додатково до видимої людиною інформації на кожній сторінці присутня також і службова інформація, що дозволяє ефективно використовувати дані програмними агентами. У свою чергу онтології є складовою частиною глобального бачення «Семантичного Вебу».

Також, як можна бачити з рисунка 1, на верхньому рівні має бути оцінка інформації з точки зору довіри до неї. Паралельно з цією проблемою виникає іще одна: в майбутньому, зв'язавши усі дані через Cемантичний Веб, як результат пошуку отримуватимемо усю інформацію (в значенні весь Веб), оскільки просто не розробляється механізм зупинки пошуку, а уся інформація буде зв'язана в монолітну структуру.

Повинен забезпечуватися індивідуальний пошук інформації - для конкретних цілей і людей. Відпо- відно, потрібен деякий спільний критерій оцінки інформації, актуальних знань та результату їх взаємодії. 3 цією метою розробляється «спектр знань». Це спроба на питання підібрати відповідь, котра не тільки необхідна, але й цікава і зрозуміла суб' єкту, відфільтровуючи при цьому «інформаційний шум».

Основними виступають наступні дві гіпотези:

- уся інформація сприймається суб'єктивно (через призму набутих знань і досвіду);

- знання суб 'єкта не є постійними і остаточно правдивими: вони змінюються і навіть певною мірою ігноруються (яскравим прикладом є загадки, котрі розв'язують люди, але не $з$ допомогою формальної логіки).

Виходячи зі сказаного, будь-який пошук повинен спиратися не тільки на сам запит, але й на індивідуальні особливості особи. Тобто пошуковий агент, вибираючи інформацію, повинен за допомогою інтерпретатора оцінити ії рівень сприйняття, відповідно приймаючи рішення про необхідність відображення цієї інформації користувачу (рис. 2).

Необхідний критерій для аналізу матеріалу і набутих знань, а також можливість оцінки їх взаємодії. Тільки після цього, аналізуючи текст і оцінюючи його через призму набутих суб'єктом знань, можливо прийняти рішення щодо видачі матеріалу користувачу. 


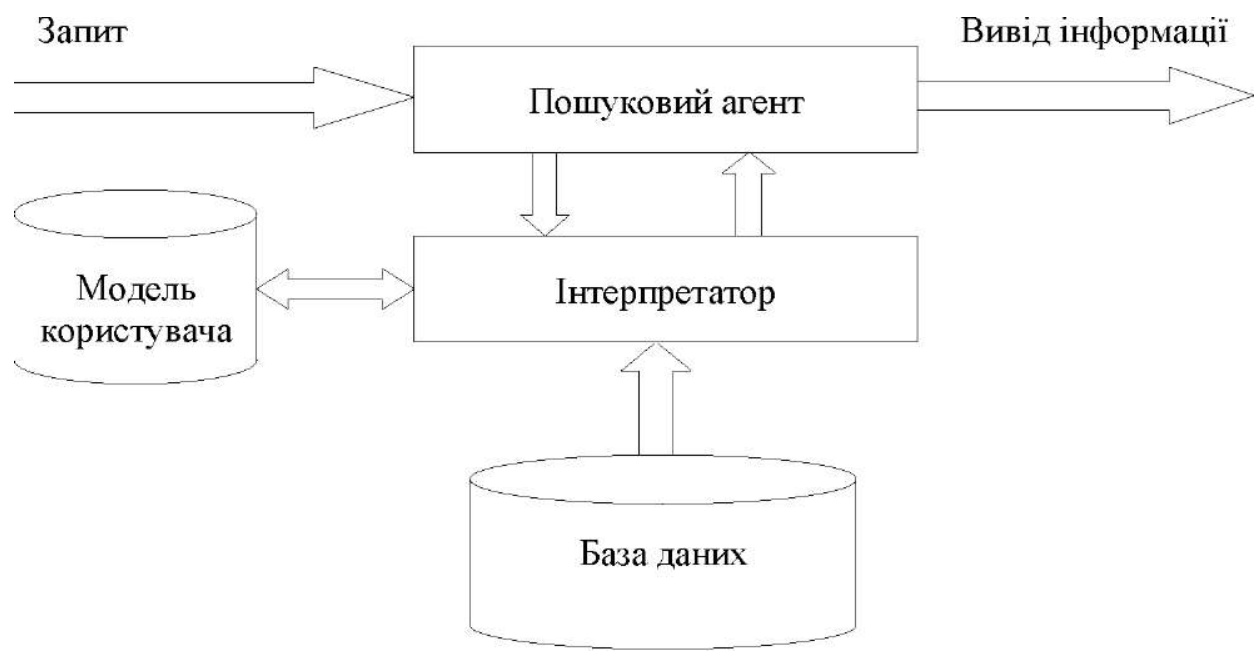

Puc. 2. Індивідуалізований пошук.

При аналізі тексту за допомогою «спектра знань» представимо його як сукупність «блоків» навчального матеріалу. Тепер сформуємо ідентифікатор блоку матеріалу. Для цього кожен блок попередньо розіб'ємо на частини: основні (в них ведеться виклад матеріалу) і пояснювальні (підказки, приклади тощо). Послідовно ідентифікуємо всі слова та словосполучення, відносячи їх до певної категорії універсальної десяткової класифікації (УДК) і ставлячи у відповідність до смуги спектра видимого випромінювання. Вираховуючи різницю частоти повторень певного слова (словосполучення) і «ключем блоку» ми отримаємо іще одну характеристику - важливість частини блоку (яскравість). Після під сумував ння отриманих даних множина основних частин дасть основний «спектр знань», а пояснювальних «підспектр знань». Цей процес можна представити у вигляді (1):

$$
F\left(x, y, x_{0}\right),
$$

де $x_{0}$ - «ключ блоку» (належність блоку і ключових слів до певних категорій УДК);

$x \in[0 ; 370]$ - множина значень (видиме випромінювання),$x=\lambda-380$;

$y \in[0 ; 1]$ - важливість частини блоку (яскравість).

Визначаючи спосіб представлення матеріалу через $z=z_{0}$ отримаємо спектр блоку матеріалу (2):

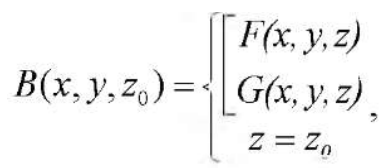

де $G\left(x, y, x_{0}\right)$ - «підспектр знань» (спектр тих частин, які служать для пояснення або розширення матеріалу).
Оскільки передбачається можливість використання одного блоку матеріалу у кількох лекціях і курсах, може виникнути необхідність провести коректування спектра блоку відповідно до змісту матеріалу, викладеного у курсі. 3 цією метою введемо корегуючу функцію v(x), котра коректує яскравість блоку відповідно до тематики лекції, при цьому $\forall x: 0 \leq v(x) \leq 1$.

Для оцінки складності вивчення використаємо характеристичну функцію складності (3):

$$
t\left(x_{i}\right)=\left\{\begin{array}{c}
v(x) \cdot y(x), x=x_{i} \\
0, x \neq x_{i}
\end{array},\right.
$$

де $x_{i}$ - характеристична точка або ключ $i$-го блоку.

Критерієм індивідуальної складності вивчення буце $t\left(x_{i}{ }^{\prime}\right)$, у котрій «ключ блоку» замінений на «спектр знань» користувача. При цьому індивідуальна складність вивчення виступає критерієм необхідності подачі інформації, а також оцінка ії взаємодії з індивідуальними знаннями.

Тому безперечно перевагами використання «спектра знань» виступають: незалежність від розмітки тексту, як наслідок - складність прив'язування «інформаційного шуму» до необхідної інформації та можливість як самостійного використання для представлення знань, так і спільно із семантичною мережею чи фреймами з будь-яким ступенем вкладеності. Одночасно забезпечуються індивідуальний підхід до кожного суб'єкта, можливість досягнення високих показників ревалентності пошуку.

Можна відмітити і недоліки «спектра знань»:

- Неможливість виводу нових знань із існуючих, оскільки сама ідея суб'єктивного сприйняття не дозволяє однозначно для всіх представити знання 
(проте «спектр знань» можна використовувати спільно із іншими моделями представлення знань).

- Використання класифікації УДК хоча і є універсальним рішенням для використання і впровадження спектра, в майбутньому вимагатиме переоцінки i переформування УДК.

- Побудова спектра вимагає значних затрат обчислювальних ресурсів ЕОМ для його динамічної побудови і оцінки для кожного суб 'єкта.

- Необхідність великої бази даних матеріалу для ефективної роботи спектра;

- Необхідність побудови системи збереження та опрацювання інформації про знання особи.

Висновки. 1. Семантичний Веб може бути вельми корисний для дистанційного навчання (ДН) оскільки містить велику базу матеріалу, а його функ-

\section{Лiтература}

1. The Twenty-first National Conference on Artificial Intelligence (AАAI-06) [Електронний ресурс]. - Режим доступу: URL: http://www.aaai.org/Conferences/AAAI/ aaai06.php. - Назва з екрана.

2. ФедорукП. І. Адаптивна система дистанційного навчання та контролю знань на базі інтелектуальних Internet-Texнологій / П. І. Федорук // Івано-Франківськ : Видавничодизайнерський відділ ЦІТ Прикарпатського національного університету імені Василя Стефаника, 2008. - 326 с. ціонування зближує з цілями навчання, розвитку творчості і спільної роботи користувачів, аналогічно ДН. 3 точки зору інтелектуальних агентів, метою буде більш «машино-орієнтований» Веб і більш ефективне використання пошукових агентів для пошуку та обробки інформації.

2. Пошук нових концепцій розвитку Веб і ДН гостро необхідний для ефективного їх розвитку.

3. Запропонований альтернативний варіант ідентифікації і побудови взаємозв'язку інформації та набутих знань на основі розробленого методу «спектр знань».

4. Запропоновано критерій оцінки взаємодії певної інформації з індивідуальними знаннями на основі оцінки складності вивчення матеріалу «спектра знань».

3. Машбиц Е. И. Психологические основы управления учебной деятельностью/Е. И. Машбиц. - К.: Вища школа, 1987.-224 c.

4. Brusilovsky P. Layered evaluation of adaptive learning systems / P. Brusilovsky, C. Karagiannidis, D. Sampson // International Journal of Continuing Engineering Education and Lifelong Learning. -2004. -№ 14 (4/5). - C. 402-421. 